魚類由来培養細胞の魚類 ノダウイルス感受性

\author{
渡辺研一 ${ }^{1 *} \cdot$ 吉水 守 $^{2}$
}

(1999年 5 月31日受付)

\section{Susceptibility of Fish Cell Lines Against Fish Nodavirus}

\author{
Ken-ichi Watanabe ${ }^{1 *}$ and Mamoru Yoshimizu ${ }^{2}$ \\ ${ }^{1 *}$ Akkeshi Station of Japan Sea-Farming Association \\ Chikushikoi, Akkeshi, Hokkaido 088-1108, Japan \\ ${ }^{2}$ Laboratory of Biochemical Process Technology, Faculty of \\ Fisheries, Hokkaido University, Minato, \\ Hokkaido, 041-0821, Japan
}

(Received May 31, 1999)

Susceptibility of 32 fish cell lines against fish nodaviruses from moribund barfin flounder (Verasper moseri, BFNNV), greasy grouper (Epinephelus tauvina, GGNNV) and striped jack (Pseudocaranx dentex, SJNNV) was investigated. Cytopathic effects were observed on SSN-1 cells inoculated with the 3 viruses at 15 or $20^{\circ} \mathrm{C}$, and on SBK-2 and SK, both derived from sea bass (Lates calcarifer), inoculated with GGNNV. Viral infectivity of homogenized brain and eye of moribund barfin flounder and Japanese flounder (Paralichthys olivaceus) juveniles were $10^{7.55 \sim 8.55}$ and $10^{6.05 \sim 6.55}$, respectively and whole bodies of striped jack larvae were $10^{8.80 \sim>9.80}$ $\mathrm{TCID}_{50} / \mathrm{g}$.

Key words: fish nodavirus, SSN-1, susceptibility, viral nervous necrosis, fish cell line

海産魚類の放流を目的とした種苗生産が行われている が，その成否に疾病発生の有無が多大な影響を与えてい $る^{1)}$ 。ウイルス性神経壊死症（viral nervous necrosis; VNN）は宿主範囲が広く，大きな問題となっている2）。 VNN ウイルスは長い間培養することができなかったが, Frerichs et al. ${ }^{3)}$ および Lim et al. ${ }^{4)}$ が，それぞれストラ イプドスネークヘッド（Channa striatus）由来の SSN-1 細胞およびシーバス（Lates calcarifer）由来の SB 細胞 を用いて原因ウイルスの分離を報告している。

本研究ではSSN-1，および SB と同一魚種由来である

\footnotetext{
1 (社) 日本栽培漁業協会厚岸事業場

2 北海道大学水産学部生物化学工学講座

* Corresponding author

E-mail: kenichi@marimo.or.jp
}

SBK-2，SK 細胞を含む温水性淡水魚11種，海産魚 8 種 ならびにサケ科魚類 6 種, 計25魚種由来の32種類の魚類 培養細胞を供試し, シマアジ (Pseudocaranx dentex), ヒトミハタ（Epinephelus tauvina）およびマツカワ (Verasper moseri) 病魚由来ノダウイルスに対する感受 性を検討した。また，SSN-1 細胞を用いて VNN 䍜病魚 のウイルス感染価の測定を試みた。

魚類培養細胞の魚類ノダウイルスに対する感受性の検 討は，供試ウイルスとして1991年のシマアジ仔魚由来 SJNNV 1991株5)，1993年のマツカワ稚魚由来 BFNNV 1993株6)，1991年のヒトミハ夕由来 GGNNV 1991株4) を用いて行った。SJNNV および BFNNV は SSN-1 細胞 で，GGNNV は SB 細胞で培養した。いずれのウイルス 株も SJNNV 特異 $\mathrm{PCR}^{7)}$ で反応陽性を示し, 抗 SJNNV 家鬼血清で中和されたものを用いた。

細胞と使用した培地を Table 1 に示した。培地は10\% 牛胎児血清（FBS; Gibco）, $100 \mathrm{IU} / \mathrm{mL}$ のペニシリン G (Sigma)， $100 \mu \mathrm{g} / \mathrm{mL}$ の硫酸ストレプトマイシン

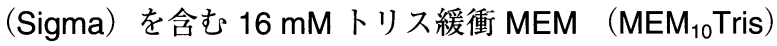
あるいは同量の FBS および抗生物質添加 L-15 培地を用 いた。細胞は細胞培養用 24 well プレート（Falcon）に $2.0 \times 10^{5} \mathrm{cells} / \mathrm{mL} / \mathrm{well}$ となるように播き， $20^{\circ} \mathrm{C}$ で 3 日 間培養した。細胞が80〜100\% confluentになった時，供 試ウイルス液を M. O.I. が約 0.1 となるように $100 \mu$ Lず つ 2 well に接種し, BFNNV を接種した細胞は $15^{\circ} \mathrm{C} て ゙$, SJNNV および GGNNV を接種した細胞は $20^{\circ} \mathrm{C} て ゙$ 培養 した。2 週間後に同種細胞に継代し，10日間観察した。

供試した32種類の細胞の BFNNV，GGNNV および SJNNV に対する感受性を Table 1 に示した。初回接種 時に細胞に変化が見られた細胞は供試した32種類のうち 10種類であった。Fig. 1 にSN-1 細胞に見られた細胞 の膨化と顆粒様物質を含む球形細胞の出現を特徵とする 変化を示した。

同種細胞に継代後も細胞に変化が見られ，CPE と判定 された細胞はSSN-1 と GGNNVを接種したSBK-2 およ びSKのみであった（Table 1)。したがって，今回調査 した細胞の中では SSN-1 細胞が魚類ノダウイルスを分 離するのに最も適していると考えられた。

罹病魚体中のウイルス感染価測定には， $-80^{\circ} \mathrm{C}$ に保 存してあった1991年の罹病シマアジ仔魚（全長 3.7〜 $3.8 \mathrm{~mm}$ ), 1993年の罹病マツカワ稚魚（全長 45 63 $\mathrm{mm}$ ）㧍よび1998年の䍜病ヒラメ稚魚（全長 18２0 $\mathrm{mm}$ ）を供試した。マッカワおよびヒラメでは病魚 5 尾 の脳および眼を個体別に, シマアジでは 5 尾プールの全 魚体 3 検体を Hanks' BSS（Gibco）でホモジナイズし, $0.45 \mu \mathrm{m}$ フィルター（ミリポア，HA）で滤過除菌した。 ホモジナイズ滤液を $10^{8}$ 倍まで希釈して，ウイルス感染価 をSSN-1 細胞を用いて測定し, 検体 $1 \mathrm{~g}$ あたりの感染価 
Table 1. Susceptibility of fish cell lines against fish nodavirus

\begin{tabular}{|c|c|c|c|c|c|c|c|c|}
\hline \multirow{3}{*}{ Cell line $\theta^{* 1}$} & \multirow{3}{*}{ Species (Tissue) } & \multirow{3}{*}{ Medium } & \multicolumn{6}{|c|}{ Change of cell morphology } \\
\hline & & & \multicolumn{2}{|c|}{ BFNNV } & \multicolumn{2}{|c|}{ GGNNV } & \multicolumn{2}{|c|}{ SJNNV } \\
\hline & & & $1 \mathrm{st}^{* 2}$ & $2 n d^{* 3}$ & 1st & 2nd & 1st & 2nd \\
\hline GSE & Gizzardshad (embryo) & $\mathrm{MEM}^{* 4}$ & - & - & - & - & - & - \\
\hline JSKG & Japanese striped knife jaw (gonad) & $L-15^{* 5}$ & - & - & - & - & - & - \\
\hline PAS & Purplish amber jack (embryo) & $L-15$ & - & - & - & - & - & - \\
\hline SBK & Red sea bream (kidney) & MEM & + & - & + & - & + & - \\
\hline SBK-2 & Sea bass (kidney) & $L-15$ & + & - & + & $+* 6$ & + & - \\
\hline SK & Sea bass (kidney) & $L-15$ & + & - & + & $+* 6$ & + & - \\
\hline SF-2 & Smelt (Fin) & $L-15$ & + & - & + & - & + & - \\
\hline KRE & Kelp \& red spotted grouper (embryo) & MEM & + & - & + & - & + & - \\
\hline ASE & Atlantic salmon (embryo) & MEM & - & - & - & - & - & - \\
\hline $\mathrm{CHH}-1$ & Chum salmon (heart) & MEM & - & - & - & - & - & - \\
\hline $\mathrm{SE}$ & Chum salmon (embryo) & MEM & - & - & - & - & - & - \\
\hline CHSE-214 & Chinook salmon (embryo) & MEM & + & - & + & - & + & - \\
\hline $\mathrm{KO}-6$ & Kokanee salmon (ovary) & MEM & - & - & - & - & - & - \\
\hline MSE & Masu salmon (embryo) & MEM & - & - & - & - & - & - \\
\hline YNK & Masu salmon (kidney) & MEM & - & - & - & - & - & - \\
\hline RTE-2 & Rainbow trout (embryo) & MEM & - & - & - & - & - & - \\
\hline $\mathrm{RTH}$ & Rainbow trout (hepatoma) & MEM & - & - & - & - & - & - \\
\hline RTG-2 & Raínbow trout (gonad) & MEM & - & - & - & - & - & - \\
\hline RTT & Rainbow trout (tail) & MEM & - & - & - & - & - & - \\
\hline STE-137 & Steelhead trout (embryo) & MEM & + & - & + & - & + & - \\
\hline $\mathrm{BB}$ & Brown bullhead (caudal trank) & MEM & - & - & - & - & - & - \\
\hline $\mathrm{BF}-2$ & Blue gil (fin) & MEM & - & - & - & - & - & - \\
\hline $\mathrm{CCO}$ & Channel catfish (ovary) & $L-15$ & - & - & - & - & - & - \\
\hline EK-1 & Eel (kidney) & MEM & - & - & - & - & - & - \\
\hline EO-2 & Eel (ovary) & MEM & - & - & - & - & - & - \\
\hline EPC & Carp (epithelioma) & MEM & - & - & - & - & - & - \\
\hline EPG & Goldfish (epithelioma) & $L-15$ & - & - & - & - & - & - \\
\hline $\mathrm{FHM}$ & Fathead minnow (caudal trank) & $L-15$ & - & - & - & - & - & - \\
\hline $\mathrm{SHH}$ & Snake head fish (heart) & MEM & - & - & - & - & - & - \\
\hline SSN-1 & Striped snake head (whole fry) & $L-15$ & + & $t^{* 6}$ & + & $+* 6$ & + & $+* 6$ \\
\hline AF-29 & Ayu (fin) & $L-15$ & + & - & + & - & + & - \\
\hline WF-1 & Smelt (fin) & MEM & + & - & + & - & + & - \\
\hline
\end{tabular}

${ }^{* 1}$ Fish cell lines were cultured at $15^{\circ} \mathrm{C}$ (BFNNV) or $20^{\circ} \mathrm{C}$ (GPNNV and SJNNV)

$* 2$ Observe the CPE-like changes at first inoculation

*3 Observe the CPE at second inoculation

*4 Minimum essential medium (w/16 mM Tris buffer, 10\% FBS and P/S)

*5 Leibovitz L-15 (W/10\% FBS and P/S)

$*$ Cytopathic effect (CPE)

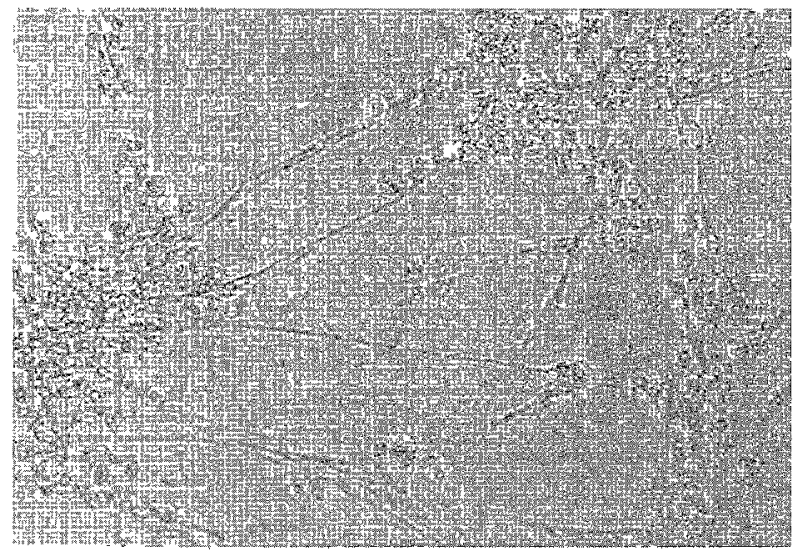

Fig. 1. Photograph showing inoculated SSN-1 cells. Inoculated with the brain and eye tissue of affected barfin flounder juvenile.

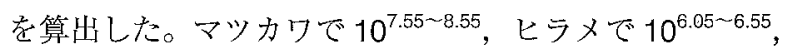
シマアジでは $10^{8.80 \sim 9.80} \mathrm{TCID}_{50} / \mathrm{g}$ であった。

SSN-1 細胞はシーバ久 (Dicentrarchus labrax) 由来 のノダウイルスを分離できることが報告されて㧍り
本研究でヒラメを含む 4 魚種由来のノダウイルスが分離 可能であったことを考充わせると，本細胞は魚類ノダ ウイルスを広く分離でき石可能性が示唆される。

\section{謝 辞}

本研究にあたり，試料を分与いただいた日本裁培漁業 拹会宮古事業場の太田健吾技術員㧤よび同上浦事業場の 森広一郎博士に感謝申し上げる。

\section{文献}

1) 西岡豊弘・古澤 徹・水田洋之介（1997）：水産增殖，45, 285-290. 2) 室賀清邦 ·古澤 徽·古澤 嶡 (1998) : 水産增 殖, 46, 473-480. 3) Frerichs, G. N., H. D. Rodger and Z. Peric (1996): J. Gen. Virol, 77, 2067-2071. 4) Lim, C. M., S. Y. Chong and M. Yoshimizu (1998): Fish Pathol., 33, 447-448. 5) Mori, K., T. Nakai, K. Muroga, M. Arimoto, K. Mushiake and I. Furusawa (1992)：Virology, 187, 368-371. 6) 渡辺研一・石間 正浩・川真田憲治・吉水 守・絵面良男 (1999) : 北大水産巢報, 50, 101-113. 7) Nishizawa, T., K. Mori, T. Nakai, I. Furusawa and K. Muroga (1994): Dis. Aquat. Org., 18, 103-107. 